\title{
The role of university community programs in disseminating agriculture innovation: a case study in Sekincau Region, West Lampung, Indonesia
}

\author{
Tumiar Katarina Manik*, Paul Benyamin Timotiwu, Agustiansyah, and Eko Pramono \\ Department of Agronomy and Horticulture, Lampung University, Indonesia
}

\begin{abstract}
Universities have three complementary missions, namely research, teaching, and community services. The Lampung University community services has responsibilities to the surround communities with being active roles in educating people, doing the strategic plans of the university, implementing and disseminating various university research results. Sekincau is a region in West Lampung with a great potential for horticulture productions, however, until recently, Lampung depends on West Java for supplying of horticulture productions. Some community programs had been done consistently in this area by Agronomy faculties of Lampung University with the local agriculture extension and farmers groups. The activities included introducing and developing good quality seeds of potato and baby beans seeds until certified for progeny of basic seed, intercropping of sorghum and baby beans, introducing internet applications useful for farmers and built a start-up particularly for young farmers. The method was "training and visit" which for regions where the level of development is still very low, instructing farmers what to do was probably more appropriate. This paper evaluated university roles in disseminating innovation to farmers. In general, it can be concluded that community development and services would only effective if continually conducted by the same group and focused on certain chosen area.
\end{abstract}

\section{Introduction}

Innovative universities conceive themselves to have three complementary missions, namely research, teaching, and community service. Community services is considered important since extension-education can be seen as an approach to enable transformative changes to occur through facilitating people to be able to help themselves, communication of innovation, facilitating learning for a better future, and as advisory services related to innovation systems [1]. In Indonesian Universities community services have certain characteristics including problem solving, comprehensive, significant and sustainable. Also, it should be multi target such as communities which is economically productive, or it could be non-productive but have strong motivation to be entrepreneurs or common people.

* Corresponding author: katarina.manik@gmail.com 
The productive communities could be craftsman, fisherman, farmers, husbandries, home industries and other communities which have some kind of business. The non-productive communities including youth group, women group, street kids, neighbourhood organization, and community health services. For these groups the objectives might be not economic development but could be better services, better environment safety, and better communities' facilities. Therefore, the objectives of extension services in Indonesia universities in general are: (a) to develop independent communities in terms of economic and social welfares, (b) to help communities in developing safety and comfortable environment and, and (c) to help communities to have certain skills such as literacy and writing, and other soft skill and hard skill needed for better life. Based on that, University of Lampung as one of public university generated the objectives corresponds to communities which are: (a) to implement the university research results which is suitable and urgent for certain communities and, (b) to offer some problem solving faced by certain communities. Lampung university community services has responsibilities to the surround communities with being active roles in educating people, doing the strategic plans of the university and implementing and disseminating to the community various university research or studies results.

The faculties as educators are also required to do community or extension services as part of university duties; on the other hand, university should facilitate and give opportunity for the faculties to do the duties. Since extension service is a significant role of university, it becomes university annual agenda and budget. There are variety schemes in conducting extension or community services in Lampung University in order to give broad opportunities for all faculties including for young faculties up to prime scheme for the experienced faculties with special obligation to build partnership with certain communities. Related to Indonesian government agendas in accelerating various development aspects in rural areas, Lampung University offers a scheme called building up rural areas in which research results should be intended for rural areas level with the objective to elevate the areas toward competitive society. Agronomy Department focused the community service in farmers community with the purpose was to disseminate knowledge, information and technology for better agriculture production and farmers' welfares. In advance the purpose should be broaden to development task including credit, supplies, marketing and markets [2]. Extension by educational institutions, especially for agricultural universities, can be the dominant approach to national extension [3]. Thus, the purpose of this paper was to evaluate the impact of University community development in agriculture rural area through evaluated the work series in Sekincau, West Lampung, Indonesia.

\section{Methodology}

\subsection{Area and design of the study}

The study focused on one of the rural areas that has been continuously nurtured by Lampung university, namely Sekincau a district in West Lampung, Indonesia (700-1000 m asl, 11.828 Ha). There are about 8 farmer groups in this sub-district and most of them are active under supervision of the rural extensions service. Main crops in this area were cabbage, tomatoes, Chinese cabbage, carrots, and chili beside coffee and pepper. In general farmers' life in this area is considered as moderate since this is the area of central vegetables production in Lampung. However, up to recent Lampung Province still depend on West Java areas for fulfilling vegetables or horticulture production demand; therefore, Sekincau should be motivated to increase their production and varied the crops species grown in this area so that Sekincau could be the sole source of vegetable and flower suppliers for Lampung Province. It could also shorten the transportation line and eventually shorten the carbon print. 
The output of this community development was to increase the production of horticultural varieties and yields by the individual farmers in Sekincau by improving the agricultural technology and introduce some new crops. Therefore, the output would contribute to an increase the production of horticultural yields in the whole project target area.

Selecting an appropriate area for community development with a purpose to production increase was suggested to follow these criteria: there are potential markets for different highvalue crops or products that can be successfully produced in the area, agro-ecological conditions of the selected area suited for those promising crops, transportation is available and in good condition so the products could be easily marketed, and there were sufficient number of different farmer associations that produced different high-value crops/products [4]. Sekincau was considered fit to those criteria. Transferring knowledge in Sekincau was conducted under the Lampung University extension scheme. Preliminary information of the area came from some alumni that worked in the area as government extension officers also from observation during research field activities, and then the teams proposed to the university for the planned community development projects every year and consistently chose Sekincau as the target area.

\subsection{Methods of dissemination}

Table 1 showed the reviewing situations and planning in conducting the community development in Sekincau. The main method to disseminate new crops production knowledge among Sekincau farmers was the Training and Visit $(T \& V)$ method. Training and Visit $(\mathrm{T} \& \mathrm{~V})$ method was debuted in the late-1960s as a reform of ineffective general extension services [3]. The Training and Visit system ( $\mathrm{T} \& \mathrm{~V}$ ) was a "top-down" approach initiated by the World Bank during the 1970s and ' 80 s. In this system, methodologies promoting the adoption of technologies were disseminated to groups of farmers within a specified time. The "T \& V system is based on the premise that a combination of factors, such as the right technology, effective and timely delivery of messages, regular extension- farmer contact, and regular training are pre-requisites for an effective agricultural development program [5]. In this method, planning, visiting time and strategies were controlled by the team and farmers and field personnel tend to depend on central resources. This method was chosen since the emphasis was on disseminating unsophisticated, low-cost improved practices, and teaching farmers to make best use of available resources. In this Sekincau community services, the first step before doing field works were preparing training materials. The trainings and visits were conducted both indoor as informal class or discussions and in field with crops demonstration plot and these activities were conducted regularly. An evaluation should be made before and after the training activities in order to know how effective the training was.

The team would come regularly to the area both in maintaining the plots and to discuss with the farmers about some problems that might emerge on the way. By the end of some particular project an evaluation should be made to decide what the continuing program that could be proposed. With this scheme it is expected that agriculture innovation could be transferred. However, due to pandemic situation in 2020 all field works were cancelled, and online evaluation was set even though it did not work as planned. 
Table 1. Reviewing Situations and planning in conducting the community development in Sekincau

\begin{tabular}{|c|c|c|c|}
\hline Problems trying to solve & $\begin{array}{l}\text { What would make } \\
\text { change happen? } \\
\text { (Rationale) }\end{array}$ & $\begin{array}{l}\text { Plan to make change } \\
\text { happen? (Aims and } \\
\text { Objectives) }\end{array}$ & $\begin{array}{l}\text { Results expected } \\
\text { (Outcomes) }\end{array}$ \\
\hline $\begin{array}{l}\text { Analysis } \\
\text { Sekincau needs to broad its } \\
\text { horticulture product to meet } \\
\text { the need of the city (Bandar } \\
\text { Lampung) }\end{array}$ & $\begin{array}{l}\text { 1. Introducing new } \\
\text { varieties is needed to } \\
\text { increase farmers income } \\
\text { 2. A new way to sell } \\
\text { their products is needed } \\
\text { to reach more customers }\end{array}$ & $\begin{array}{l}\text { Profile farmers crops, } \\
\text { Draw up an action } \\
\text { plan with short- and } \\
\text { medium-term } \\
\text { objectives to guide } \\
\text { work } \\
\end{array}$ & $\begin{array}{l}\text { Sekincau } \\
\text { could be the } \\
\text { central of } \\
\text { horticulture } \\
\text { products in } \\
\text { Lampung } \\
\end{array}$ \\
\hline $\begin{array}{l}\text { Engagement } \\
\text { Farmers are engaged; } \\
\text { however, they are not able } \\
\text { to broad their thought of } \\
\text { what is necessary for their } \\
\text { activities }\end{array}$ & $\begin{array}{l}\text { Community } \\
\text { development is } \\
\text { needed to encourage } \\
\text { people to broad their } \\
\text { knowledge }\end{array}$ & $\begin{array}{l}\text { Set up community } \\
\text { development and outreach } \\
\text { projects } \\
\text { Develop a strategy to } \\
\text { communicate with } \\
\text { farmers about the } \\
\text { activities are all about: } \\
\text { informal trainings }\end{array}$ & $\begin{array}{l}\text { Farmers } \\
\text { communities are } \\
\text { engaged in a } \\
\text { variety of } \\
\text { informal trainings } \\
\text { and tackling } \\
\text { local problems } \\
\text { and development }\end{array}$ \\
\hline $\begin{array}{l}\text { Capacity } \\
\text { Adequate leadership, } \\
\text { organizational } \\
\text { Ability and level of skills; } \\
\text { low level of resources and } \\
\text { new technologies }\end{array}$ & $\begin{array}{l}\text { Constant } \\
\text { communication } \\
\text { and visitation are } \\
\text { needed to make } \\
\text { them connected to } \\
\text { situation outside } \\
\text { their area }\end{array}$ & $\begin{array}{l}\text { Provide activities to develop: } \\
\text { - knowledge of horticulture } \\
\text { products and management: } \\
\text { Demonstration plots: baby green } \\
\text { beans, strawberry, head } \\
\text { lettuces, potatoes } \\
\text { - internet skills: AGROPED }\end{array}$ & $\begin{array}{l}\text { More horticulture } \\
\text { products are grown in } \\
\text { this area and farmers } \\
\text { interested in using } \\
\text { internet in selling their } \\
\text { products }\end{array}$ \\
\hline
\end{tabular}

\subsection{Methods of gathering information for evaluation}

\subsubsection{Feedback forms}

To find out whether farmers have found the training and other events useful they were asked to fill in a short form. There were two subjects of trainings that have been done: first, applying internet applications in developing horticulture cultivation in Sekincau, West Lampung.

Second training was introducing baby green beans cultivation and seed production. Before the training all farmers never experienced to plant this crop. Following the training demonstration plots were set up and evaluated on the harvest time.

\subsubsection{Yield of plot demonstration}

In developing potatoes with good quality seeds, we did not set a training since the farmers in this area have experienced planting potatoes. Directly set plot demonstrations with the aim to compare between the yield from their seeds with the seeds from Lembang, West Java we introduced. Similar activities with introducing new potential crops: Strawberry and head lettuce, these crops have been planted as house yard with no intention to develop the crops for commercial purpose.

Specific indicators for subsectors of Agriculture and Rural Development could be evaluated in three levels [6]:

1. Early outcome: if the participants applied and satisfied with the trainings involving introduced crops practices, new technologies and higher crops production

2. Medium-term outcome: if there is percentage change in yields of introduced crops of the country 
3. Long-term outcome: if there is yield gap between farmers' yields and on-station yields for the introduced crops of the area and percentage of total land area planted with the introduced crops

\section{Results}

\subsection{Introducing new potential crops and technologies}

There were four new crops which were introduced in this area that predicted would have good market and economic value: baby green beans, potatoes, strawberries and head lettuce and on-going works would be chrysanthemum flower and sorghum.

\subsubsection{Baby green beans}

Farmers in Lampung, has been accustomed planting long, trailing vine type of green bean and sold the young beans as vegetable, but they were not able to produces the seeds. Balai Penelitian Sayuran Lembang (BALITSA/Vegetable Research Centre) recently developed a new green beans strain called LE-155 or called erected baby green beans that not need any trail to grow. This bean has shorter harvest day, better taste and crunchy which is favorable for side dish and with high productivity. Cultivation of this new strain and the technique to produce the seeds was introduced to farmers group SukaTani Sejahtera, Sekincau. With training and demonstration plot, farmers had been able to produce certified seed which is progeny of basic seed. Beside introduced the new baby green beans strain, it also continued with training of developing the seeds so that farmers could multiplied seeds for further productions.

The results showed that after tried by themselves, 100 percent participants was able to plant this crop and also produced seeds that qualified as the certified seed. This seed level was qualified for commercial purposes. However, only 20 percent was interested in developing their own seed. Farmers was able to produce certified seeds with the product 375 $\mathrm{kg}$ seeds/ha which is quite high

\subsubsection{Strawberry and head lettuce}

Strawberries and head lettuce have not been grown in Sekincau commercially, when certainly it could be grown there since the altitude and the air temperature was suitable. With growing culinary industries in Bandar Lampung it is predicted that markets for this fruit/crops will be prospective. 


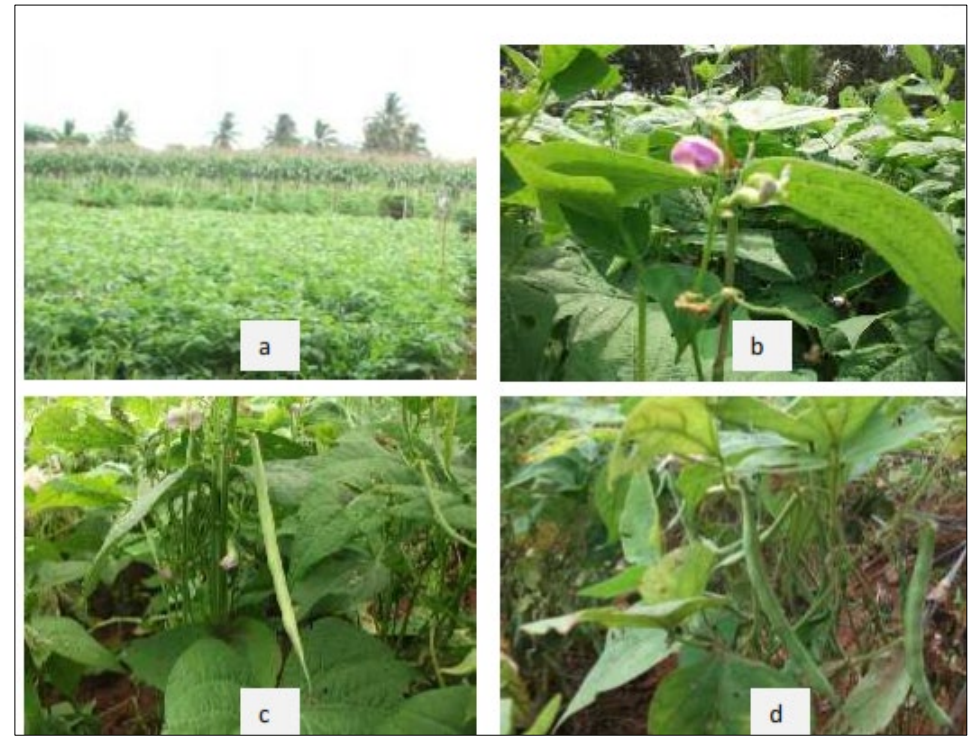

Fig. 1. The green beans field: a. vegetative stage, b. flowering, c. pod filling and d. harvest

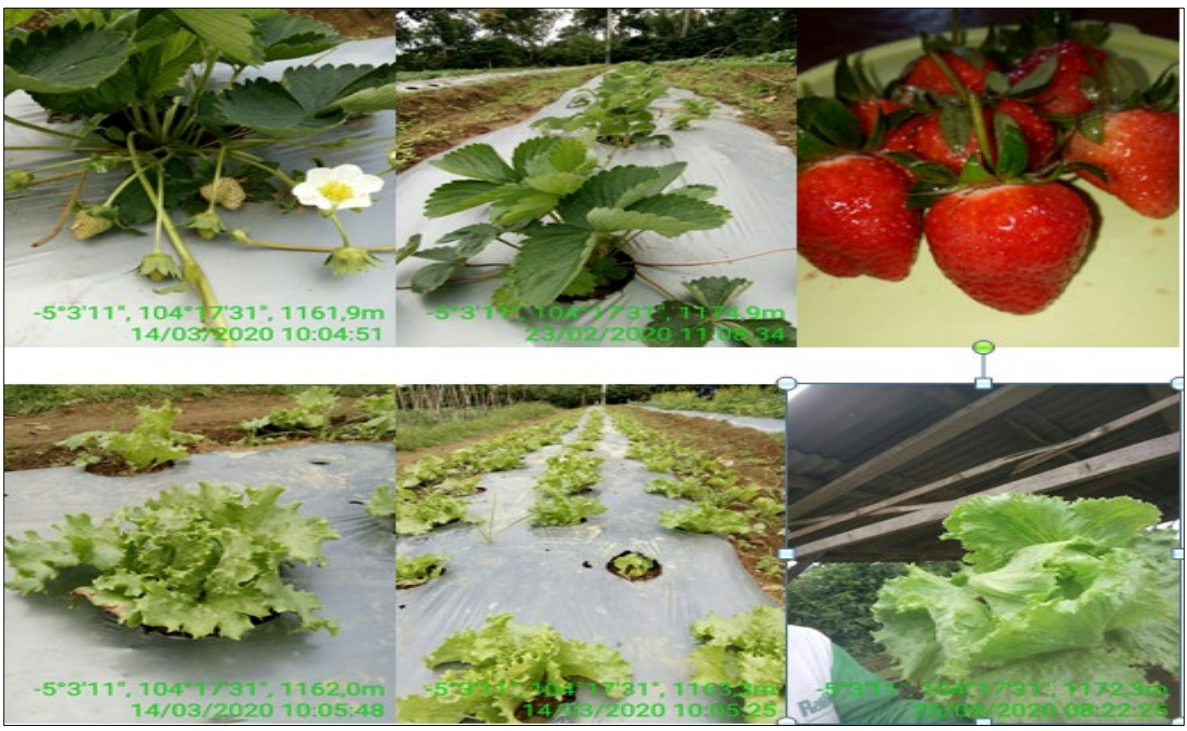

Fig. 2. New potential crops: Strawberry and Head Lettuce introduced in Sekincau

Since the purpose of the plot demonstration approach was to induce farmers to plant these crops with commercial purposes, yield has not been evaluated yet.

\subsubsection{Potatoes}

Potatoes has been grown in Sekincau, however farmers used poor quality seeds; therefore, introducing high quality seeds were necessary for better products. Potatoes production from quality seed was higher (20 ton/ha) than national average 18.7 ton/ha 


\subsection{Introducing internet application that related to farmers}

With the pandemic (maybe even before) internet applications were boomed and enough numbers are related to agriculture. With the thought that farmers' communities should improve themselves and should not avoid this new development, some of the internet applications were introduced to the farmers' communities. Some applications that being introduced on the short training were: My Agri, KATAM, Budidaya Tanaman Sayuran, Sistim Pakar Kopi, and Tanam.

The results showed that all participants did not know that internet application could be used for agriculture productions, 40 percent have used internet in their smartphone especially for communications, 30 percent thought internet was a difficult tool. After the training they understood that internet was useful but prefer more to get information directly from their group or extension workers. They also still precept those applications in internet that has been introduced on the training (My Agri, KATAM, Pakar Kopi and TANAM) were not easy to understand. Our conclusion was it should be only one or two applications explained on the training.

\subsection{Developing simple startup initially limited for the local farmers}

It was unpredictable that the pandemic was uncertainly continued, that all field works were canceled. During this passive time, the idea of developing simple startup was considered and came out with AGROPED. AGROPED developed to help farmers to sell and buy agriculture product and needs; however, AGROPED is not only for commercial but also functioned for consultations and for getting information. Recently, visiting field was possible, with following the health regulations strictly; next step to socialize AGROPED to farmers group is planned.

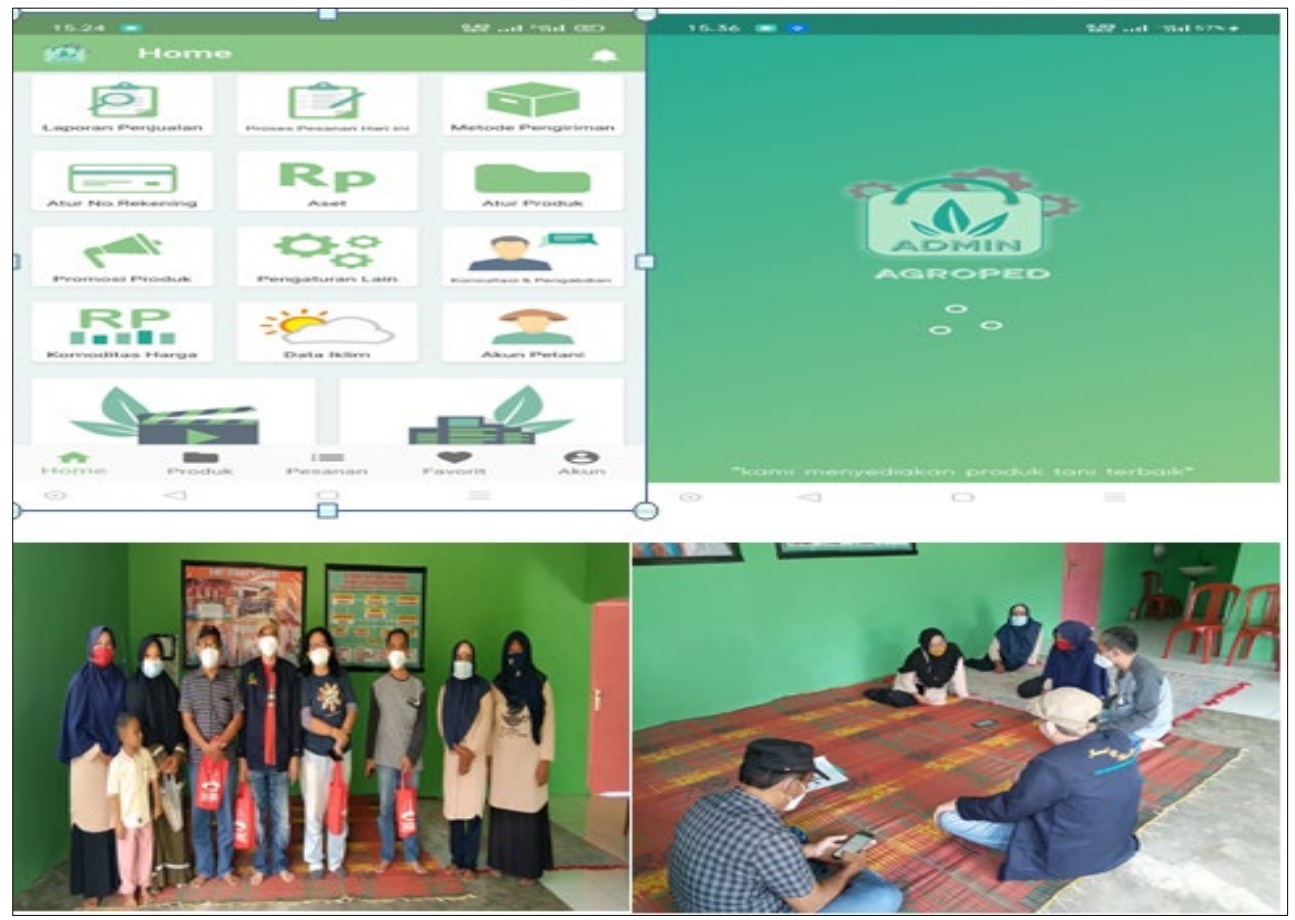

Fig. 3. AGROPED face and socialisation internet aplications for farmers' group 


\subsection{Introduce new crops is continued}

Next activities at Sekincau would be introducing multi cropping sorghum and baby green beans and planting chrysanthemum flower. The background for this was beside horticulture crops, Sekincau is also potential for cattle, therefore it would need quality grains and sorghum is chosen. However, since upland area is limited and farmers would not interest to plant their fields with sorghum, multi cropping sorghum with green beans could be the alternative.

Chrysanthemum flowers market became growing because flowers are needed for celebration events such as graduation, wedding or any other events. It is observed that this flower is all transported from other province; therefore, this is a good opportunity for farmers' economic gain. Our perspective evaluation level of accomplishment of the community development following [6], was described on the Table 2.

\subsection{Evaluation level of accomplishment}

From Table 2, it was obvious that even though all programs were done continuously in one specific area (Sekincau) but the community development works were more temporary projects than a long-focused work. In [7], logic model approach; steps up to works undertaken using input was categorized just as activities since no clear output yet, or in Kirkpatrick levels that accomplishment might only reached learning level, the knowledge learnt by the participants as a result of the training program [5]. This might happen since community development in the educational institution approach, planning (budget and time) (Italic sentence on Table 1. Draw up action plan with short-and medium-term objectives to guide work) is controlled by university administration through proposal competition, and implemented through groups or individuals whose proposals were selected by university administration, and no guarantee that same team or individual would get funding for continuous projects. Moreover, attendance and the extent of participation by farmers in agricultural extension activities and participations posttest after the training were the measures of success and the output is working papers or publications, but never really emphasized on the outcome. There are also community developments schemes that implemented by students but since the time is short and the budget is limited no specific impacts could be achieved; this project was more for fulfilling the curriculum [1].

No doubt that higher agricultural education has contributed to the growth and modernization of agriculture, but it has often failed to adjust its curricula and manage the curricula to respond to the need of agriculture space especially on rural context: therefore, the connection between higher education and rural development is becoming very important, although it is not easy for universities to deal with both their universal mission of knowledge production and their contribution to the development of local communities [8].

However, community development in Sekincau was conducted on good plans and methods, as stated by Swanson [4], that community development/extension services on farmers can no longer focus its primary attention on increasing the productivity of major food staples, but must shift some of its focus to those higher-value, labor-intensive crops, or enterprises so that rural communities could increase their incomes and/or employment, and eventually improving their livelihoods. As well as the strategies which were (a) helping farmers get organized, (b) determining their interests based on accessible market opportunities, (c) training these groups in how to produce specific crops/products and (d) working with them to develop supply chains in marketing their products.

Several studies in developing countries reported that agricultural research results hardly reach farmers [9]. The other weakness of university community development was the chosen method which was the training and visit ( $\mathrm{T} \& \mathrm{~V}$ ) method. This method might be chosen by faculties since they could not stay longer on the area when actually beside farmers, the other 
consumers of information are the extension workers. These are people who are employed by government and have a certain level of education to bridge the gap between the government and the farmers [10]. Some qualitative evaluations have questioned the approach of $\mathrm{T} \& \mathrm{~V}$ as being 'top down' and lacking a means for organizing farmers to express their own demands for the community development or extension advice. Others have noted problems in implementation of $\mathrm{T} \& \mathrm{~V}$, especially the choice of contact farmers, poor research-extension links, and weak connection with farmers at the field level. In other cases, the information content of project messages only given to the contact farmers and is not disseminated to neighbouring farmers in the area [11].

Table 2. Perspective field works accomplishment and evaluation of community development in Sekincau

\begin{tabular}{|c|c|c|c|}
\hline No & Activities & Accomplishment & Evaluation \\
\hline 1. & $\begin{array}{l}\text { Introducing upright baby green } \\
\text { beans }\end{array}$ & $\begin{array}{l}\text { Baby green beans grows } \\
\text { well in Sekincau }\end{array}$ & $\begin{array}{l}\text { Has not been adopted } \\
\text { by majority farmers } \\
\text { since they planted crops } \\
\text { following local market } \\
\text { needs: early outcome }\end{array}$ \\
\hline 2. & $\begin{array}{l}\text { Developing baby green beans } \\
\text { seeds }\end{array}$ & $\begin{array}{l}\text { Farmers was able to } \\
\text { produce certified seeds with } \\
\text { the product } 375 \mathrm{~kg} \text { seeds/ha } \\
\text { which is quite high }\end{array}$ & Media term outcome \\
\hline 3. & $\begin{array}{l}\text { Introducing good quality potatoes } \\
\text { seeds }\end{array}$ & $\begin{array}{c}\text { Potatoes production was } \\
\text { higher ( } 20 \text { ton/ha) than } \\
\text { national average } 18.7 \\
\text { ton/ha. Farmers started use } \\
\text { the quality seeds }\end{array}$ & Long term outcome \\
\hline 4. & $\begin{array}{l}\text { Introducing internet application } \\
\text { that related to farmers }\end{array}$ & $\begin{array}{l}\text { - Farmers interested on } \\
\text { some applications; they } \\
\text { have used some of that } \\
\text { but still prefer to get } \\
\text { direct information } \\
\text { - Farmers gave good } \\
\text { responses on the first } \\
\text { online questionnaire, but } \\
\text { getting slower response } \\
\text { on the next questionnaire }\end{array}$ & Early outcome \\
\hline 5. & $\begin{array}{l}\text { Developing simple startup initially } \\
\text { limited for the local farmers }\end{array}$ & $\begin{array}{l}\text { This application will be } \\
\text { focus on some farmers } \\
\text { group that has commercial } \\
\text { products (mostly coffee); } \\
\text { have not been released yet }\end{array}$ & No evaluation available \\
\hline 6. & $\begin{array}{l}\text { Introducing multi cropping } \\
\text { Sorghum and baby beans }\end{array}$ & $\begin{array}{l}\text { By this time the field for } \\
\text { demonstration plots are } \\
\text { being prepared }\end{array}$ & No evaluation available \\
\hline 7 & $\begin{array}{l}\text { Introducing chrysanthemum } \\
\text { flower }\end{array}$ & $\begin{array}{l}\text { This activity will be held on } \\
\text { farmers field and their first } \\
\text { responses were good, they } \\
\text { know that this flower has a } \\
\text { good market }\end{array}$ & Early outcome \\
\hline
\end{tabular}

Training and visit method were appropriate for farmers or rural community which the level of development was low and the technology being introduced was not sophisticated. 
[5], reported that extension officers in Nigeria have stated that when the $\mathrm{T} \& \mathrm{~V}$ system is properly organized both structurally and institutionally, it encourages professionalism; $\mathrm{T} \&$ $\mathrm{V}$ was considered as an efficient monitoring and evaluation system. The system is viewed as very flexible and encourages widespread interaction with other farmers. However, most reports consistently recommended participatory approach as the best method in conducting community development/extension services.

\section{Conclusions}

Work series in conducting community development in Sekincau, West Lampung, Indonesia had been done under University of Lampung community development scheme. Some results were applied by the farmers but some was merely information for them. However, since more works are in ongoing process until now and the team dedicated and put effort to focus on Sekincau, better results are expected in the future. University especially the Agriculture Department has an important responsibility in improving agriculture product and its community welfare. The tasks should be handled with continuous works on focused locations. The method should be up graded from $\mathrm{T} \& \mathrm{~V}$ method to participatory method and the evaluation of the community development/extension services would not enough merely on the report or published papers but should prove the long-term outcome.

\section{References}

1. S. Amanah, A. Fatchiya, Jurnal Penyuluhan, 14, 1 (2018)

2. L. German, J. Mowo, M. Kingamkono. Agriculture and Human Values, 23 (2006)

3. W. McRivera, M. K. Qamar. Agricultural Extension, Rural Development, and the Food Security Challenge. (Food And Agriculture Organization of the United Nations. Rome, 2003)

4. B. E. Swanson. Journal of International Agricultural and Extension Education, 13, 3 (2006)

5. B. William. An Evaluation of the Farmer-Training Programme in Jamaica: Opportunities for use of ICTs in training delivery and in farming activities. Proceedings of the Nineteenth Americas Conference on Information Systems, Chicago, Illinois, August 1517, (2013)

6. N. Keita, N. Okidegbe, S. Cooke, T. Marchant. Developing countries' perspective: Selecting a core set of Indicators for Monitoring and Evaluation in Agriculture and Rural Development in Less-than-Ideal Conditions and implications for countries statistical system. Wye City Group on Statistics. On Rural Development and Agriculture Household Income. Second Meeting. (FAO Head-Quarters, Italy, Rome, 2009)

7. R. Balakrishnan, A.S. Murai, Y. Kalnar, V. Kumar. Techniques for Impact Assessment of Technologies. Advancements in Post Harvest Management of Legumes for Minimizing Losses and Sustainable Protein Availability ICAR-Summer School, July 0525, 2018 (2018)

8. D. Atchoarena, K. Holmes. The Role of Agricultural Colleges and Universities in Rural Development and Lifelong Learning in Asia. Paper presented at the 15th Conference of the Asian Association of Agricultural Colleges and Universities, held in Nagoya, Japan on $27-30$ September 2004 (2004)

9. F. Sulaiman. FAE., 20, 2 (2002)

10. L. Sani, B.Y. Boadi, O. Oladokun, T. Kalusopa. IOSR Journal of Agriculture and Veterinary Science, 7, 2 (2014) 
11. S.S. Hussain, D. Byerlee, P.W. Heisey. Impacts of the training and visit extension system on farmers' knowledge and adoption of technology: Evidence from Pakistan Agricultural Economics, 10 (1994) 